\title{
(2) OPEN ACCESS \\ How to use Donath-Landsteiner test to diagnose paroxysmal cold haemoglobinuria (PCH)
}

\author{
Jennifer Delun Williams (D) ,' Ram K Jayaprakash, ${ }^{2}$ Heena Kithany, ${ }^{1}$ \\ Mark Peter Tighe (D) ${ }^{1}$
}

- Additional supplemental material is published online only. To view, please visit the journal online (http://dx.doi. org/10.1136/archdischild2020-319568)

${ }^{1}$ Paediatrics, University Hospitals Dorset NHS Foundation Trust, Poole, UK

${ }^{2}$ Haematology, University Hospitals Dorset NHS

Foundation Trust, Poole, UK

\section{Correspondence to}

Dr Mark Peter Tighe, Paediatrics, University Hospitals Dorset NHS Foundation Trust, Poole BH15 2JB, Bournemouth Christchurch, UK; mpt195@hotmail.com

Accepted 16 June 202

\begin{abstract}
Paroxysmal cold haemoglobinuria (PCH) accounts for around a third of cases of autoimmune haemolytic anaemia in children. PCH is caused by an autoantibody that fixes complement to red cells at low temperatures and dissociates at warmer temperatures (a biphasic haemolysin), triggering complement-mediated intravascular haemolysis. Named the Donath-Landsteiner (D-L) antibody after its discoverers, it is usually formed in response to infection and demonstrates specificity for the ubiquitous red cell P-antigen. A D-L test can be used to detect the presence of the D-L autoantibody in the patients' serum. Here we discuss the use of the D-L test in identifying PCH in a 2-year-old boy who presented with haemolytic anaemia. A summary of the key information can be found in the infographic.
\end{abstract}

\section{BACKGROUND}

Haemolytic anaemias occur in two major types according to aetiology: intrinsic and extrinsic. ${ }^{2}$ Intrinsic haemolytic anaemias are usually inherited and caused by a defect in the red blood cell (RBC) itself leading to premature RBC haemolysis. Extrinsic haemolytic anaemias are usually acquired and involve the premature destruction of the RBC by external factors such as antibodies, infections or trauma. Autoimmune haemolytic anaemia (AIHA) is an extrinsic haemolytic anaemia characterised by the production of autoantibodies that bind to the surface of RBCs leading to premature haemolysis.

Haemolysis of RBCs can occur via two mechanisms: intravascular, the destruction of RBCs in the circulation; and extravascular, the destruction of RBCs by macrophages of the spleen, liver or bone. ${ }^{2}$ Laboratory results and clinical manifestations can help differentiate between the mechanism of haemolysis. Haemolysis

\section{Case history}

History: A 2-year-old previously healthy boy presented with a 24-hour history of increased drowsiness, jaundice and generalised abdominal pain on a background of a recent coryzal illness within the last 2 weeks. Parents reported his urine was dark brown/ red like 'Coca-Cola'. There was no history of recent travel, ingested toxins or diarrhoea. The patient had an up-to-date vaccination history, no medical history or family history of haemoglobinopathies.

Physical examination: On examination, he was lethargic, cold peripherally (temperature $37.2^{\circ} \mathrm{C}$ ) with a thready pulse, had pale conjunctiva and tachycardia (HR 166 beats/min). Respiratory rate was 38 breaths/ min. A systolic flow murmur was present. There was no evidence of a rash, petechiae or bruising, no palpable hepatosplenomegaly and no neurological deficits.

Investigations: Preliminary investigations included a septic screen (blood culture, urine dipstick and microscopy and a blood gas), full blood count (FBC) and film, U\&E and LFTs. The initial FBC (figure 1) and film suggested a haemolytic anaemia within an hour. Further bloods included coagulation and a haemolytic screen (haptoglobin, split bilirubin (conjugated and unconjugated), reticulocyte count, lactate dehydrogenase (LDH) and a direct antiglobulin test (DAT) to look for an immune cause). ${ }^{1}$ In an attempt to identify an infective cause, testing for syphilis, cytomegalovirus, parvovirus, respiratory syncytial virus, coxsackie virus and mycoplasma pneumoniae was performed.

Interpretation: Acute intravascular haemolysis: severe anaemia, hyperbilirubinaemia, raised LDH, low haptoglobin and haemoglobinuria. Renal function, coagulation screen, platelets and white blood cells were within normal values. A DAT-positive for complement (C3) and negative for lgG showed that the red blood cells were coated with $\mathrm{C} 3$ and suggestive of paroxysmal cold haemoglobinuria (PCH) or a cold autoimmune haemolytic anaemia such as cold agglutinin disease ${ }^{1}$ (figure 1). The blood film obtained on day 1 showed spherocytes and red cell agglutination also in keeping with a haemolytic picture (figure 2). His blood cultures, virology and bacterial screen were negative and did not identify a cause. 


\section{Case history}

Further testing: A positive indirect Donath-Landsteiner (D-L) test confirmed the diagnosis of $\mathrm{PCH}$ and the presence of D-L antibodies (figure 3).

in AIHA can either be intravascular or extravascular, although paroxysmal cold haemoglobinuria $(\mathrm{PCH})$ is almost exclusively intravascular ${ }^{3-5}$ (figure 4).

Cases of AIHAs are generally classified according to the optimal temperature the autoantibodies bind to the patients' RBCs: warm AIHA $\left(37^{\circ} \mathrm{C}\right)$, cold AIHA $\left(<37^{\circ} \mathrm{C}\right.$ ) and mixed $\mathrm{AIHA}^{136}$ (figure 5). There are two distinct AIHAs associated with cold-reactive autoantibodies: cold haemagglutinin disease (CHAD) is more common in adults and $\mathrm{PCH}$ is significantly more common in children. ${ }^{3}$ The aetiology of AIHAs can be categorised as primary (idiopathic, approximately $50 \%$ ) and secondary to underlying disorders such as malignancy, infections or autoimmune diseases. ${ }^{67}$

Although AIHAs are rare in children in the UK, they result in lengthy admissions and carry potential morbidity if not correctly identified. The incidence of AIHA in children has been estimated at greater than three per million/year and possibly as high as 1 per $100000 /$ year. $^{8}{ }^{9}$ Studies estimate that 20\%-50\% of paediatric AIHA is caused by $\mathrm{PCH} .{ }^{10}{ }^{11} \mathrm{PCH}$ was first described in 1872, when most cases were associated with congenital syphilis. ${ }^{12} \mathrm{PCH}$ in children now more commonly occurs as an acute transient haemolysis secondary to infections $(>70 \%$ post respiratory infection), vaccinations, haematological malignancies and autoimmune disorders (figure 6). ${ }^{1}{ }^{4} 12-14$ Often the haemolysis in PCH is severe because it is intravascular; however, spontaneous resolution over several weeks, once the infection has subsided, is common. ${ }^{15}$

The autoantibody associated with $\mathrm{PCH}$ is the D-L antibody after its discoverers in 1904. An indirect D-L test is the only specific diagnostic tool available for $\mathrm{PCH} .{ }^{16}$ The D-L antibody is classically a polyclonal biphasic IgG autoantibody with specificity for the RBC P-antigen ${ }^{4}$; other non-IgG D-L antibodies, IgA and IgM, have been reported. ${ }^{17}{ }^{18}$ At low temperatures, $<37^{\circ} \mathrm{C}$, the D-L antibody fixes complement to RBCs and on heating to $37^{\circ} \mathrm{C}$ triggers complement-mediated lysis (figure 6), as the D-L bound RBCs travel from the peripheries to the core.

Difficulties associated with the D-L test have led to controversies regarding the actual incidence of $\mathrm{PCH}$. The D-L test is technical, often carried out incorrectly and may be missed in the diagnostic tests for AIHA. ${ }^{19}$

\section{CLINICALLY RELEVANT QUESTIONS}

How might a child with AIHA present clinically?

Children with AIHA commonly present with symptoms and signs of acute haemolysis: anaemia (weakness, dizziness, pallor and dyspnoea) and haemolysis (jaundice). ${ }^{1}$

\begin{tabular}{|c|c|c|}
\hline $\begin{array}{l}\text { Initial Investigations to } \\
\text { request in suspected AlHA }\end{array}$ & Patient JE Results (Day 1) & Reference Ranges \\
\hline $\begin{array}{l}\text { FBC, U+Es, LFTs } \\
\text { Reticulocytes } \\
\text { Split Bilirubin: (conjugated } \\
\text { and unconjugated) } \\
\text { LDH } \\
\text { Haptoglobins } \\
\text { Urinalysis } \\
\text { Blood Group } \\
\text { Blood Film } \\
\text { DAT screen } \\
\text { Blood Cultures } \\
\text { Infectious disease screen: } \\
\text { (Syphilis, CMV, Parvovirus, } \\
\text { RSV, Coxsackie virus, } \\
\text { mycoplasma pneumoniae) }\end{array}$ & $\begin{array}{l}\text { Haemoglobin }=47 \mathrm{~g} / \mathrm{L} \\
\text { Reticulocytes }=26 \times 10^{9} / \mathrm{L} \\
\text { Blood Film }=\text { Spherocytes, red cell } \\
\text { agglutination. } \\
\text { Urea = } 11.7 \mathrm{mmol} / \mathrm{L} \\
\text { Creatinine }=26 \mu \mathrm{mol} / \mathrm{L} \\
\text { Bilirubin: } \\
\quad \text { Total = } 83 \mu \mathrm{mol} / \mathrm{L} \\
\quad \text { Conjugated }=16 \mu \mathrm{mol} / \mathrm{L} \\
\quad \text { Unconjugated }=67 \mu \mathrm{mol} / \mathrm{L} \\
\text { LDH }>1800 \text { IU } / \mathrm{L} \\
\text { Haptoglobin }=<0.2 \mathrm{~g} / \mathrm{L} \\
\text { Urine Dipstick = +++ Blood } \\
\text { Urine Microscopy = } 3 \mathrm{RBC} / \mu \mathrm{L} \\
\text { DAT = C3 positive. IgG Negative } \\
\text { Blood Cultures = Negative } \\
\text { Infectious disease screen = Negative }\end{array}$ & $\begin{array}{c}(2.5-6.7 \mathrm{mmol} / \mathrm{L}) \\
(15-31 \mu \mathrm{mol} / \mathrm{L}) \\
(0-17 \mu \mathrm{mol} / \mathrm{L}) \\
\\
(90-275 \mathrm{lU} / \mathrm{L}) \\
(0.5-2.2 \mathrm{~g} / \mathrm{L})\end{array}$ \\
\hline
\end{tabular}

Figure 1 Column 1 shows the initial investigations for AlHA in a patient presenting with a haemolytic picture. Column 2 shows results from the initial investigations of the patient. Column 3 shows reference ranges. AlHA, autoimmune haemolytic anaemia; CMV, cytomegalovirus; DAT, direct antiglobulin test; FBC, full blood count; LDH, lactate dehydrogenase; LFT, liver function test; RBC, red blood cell; RSV, respiratory syncytial virus; U+E, urea and electrolyte. 


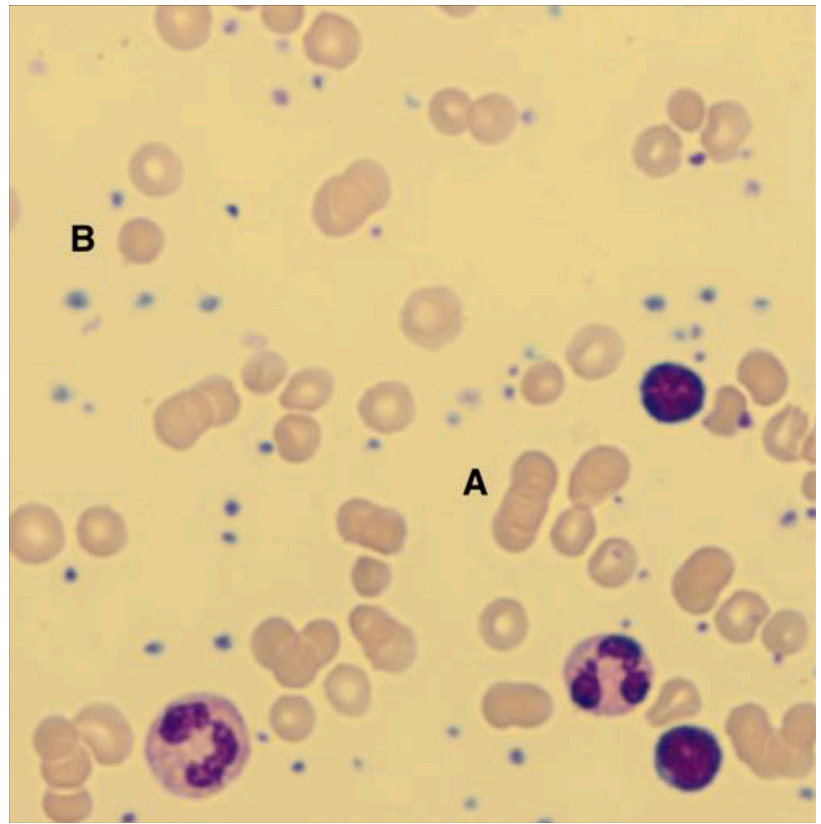

Figure 2 Red cell agglutination (A) and spherocytes (B) in the peripheral blood film of the 2-year-old patient on day 1 of his presentation with AlHA. Spherocytes are RBCs that are smaller and denser than normal RBCs due to their sphere shape rather than the RBCs' characteristic biconcave shape. Spherocytes in a blood film are most often associated with an immune-mediated haemolytic anaemia. ${ }^{23}$ AlHA, autoimmune haemolytic anaemia; RBC, red blood cell.

Non-specific symptoms may include fever, malaise, confusion, abdominal pain and back or leg pain. ${ }^{11}$ Depending on the severity of the anaemia, tachycardia and systolic flow murmurs may occur. Other physical examination findings may suggest associated conditions and/or the underlying cause, for example, lymphadenopathy and/or hepatosplenomegaly suggestive of an underlying malignancy or bruising and petechiae associated with coagulation abnormalities such as in thrombotic microangiopathy (TMA).

Examination findings may vary with the type of haemolysis involved. Hepatosplenomegaly is primarily associated with extravascular haemolysis and haemoglobinuria occurs with intravascular haemolysis, such as in $\mathrm{PCH}$, often presenting as a dark/red coca-cola coloured urine. ${ }^{1020}$

\section{What initial laboratory tests may be useful in aiding a diagnosis of haemolytic anaemia and what might you expect from these investigations?}

A haemolytic screen should be carried out and its result interpreted collectively: full blood count (FBC) and film, lactate dehydrogenase (LDH), split bilirubin (unconjugated and conjugated), reticulocytes, haptoglobin and urinalysis (dipstick and microscopy). ${ }^{21}$ Typical findings and limitations in interpretation are noted in figure 7 . Laboratory results in extravascular haemolysis are generally less severe, as haemolysis occurs in the reticuloendothelial system, with fewer degradation products released into the circulation. $^{21}$

Haemolysis causes anaemia if the bone marrow $\mathrm{RBC}$ production cannot compensate for increased RBC destruction. Haemoglobinuria should be suspected if the urine dipstick is positive for blood but urine microscopy shows minimal red cells. Haptoglobin, the most sensitive laboratory indicator of haemolysis and last marker to normalise, is significantly decreased due to free haemoglobin $(\mathrm{Hb})$ exceeding the $\mathrm{Hb}$-binding capacity of the circulating haptoglobins. ${ }^{5}$ A reticulocytosis is usually seen, although with AIHA reticulocytopenia can commonly occur in the acute phase due

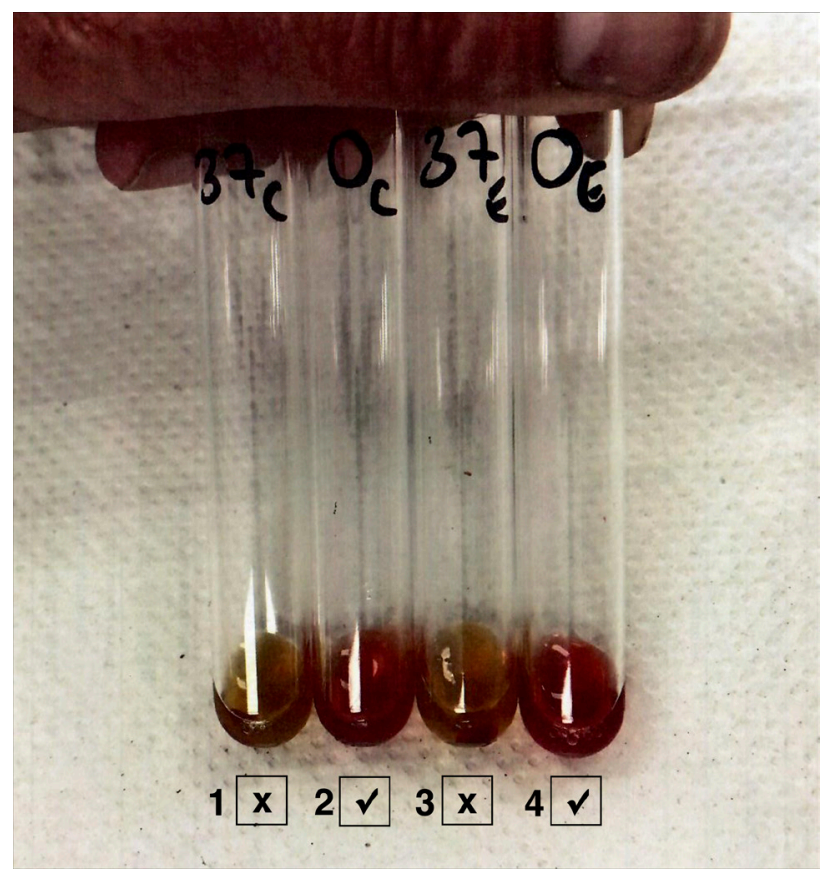

Figure 3 The patient's positive D-L test. Tube 1: the patient's serum+donor fresh serum+reagent $\mathrm{P}$-antigen-positive group 0 $\mathrm{RBC}$ incubated at $37^{\circ} \mathrm{C}$. Tube 2: duplicate of tube 1 but double incubation at $0^{\circ} \mathrm{C}$ and $37^{\circ} \mathrm{C}$. Tube 3: the patient's serum+donor fresh serum+reagent $\mathrm{P}$-antigen-positive group $\mathrm{O} \mathrm{RBC}$ treated with enzyme $1 \%$ papain at $37^{\circ} \mathrm{C}$. Tube 4 : duplicate of tube 3 but double incubation at $0^{\circ} \mathrm{C}$ followed by $37^{\circ} \mathrm{C}$. Tubes 2 and 4 both show haemolysis and thus a positive D-L test $(\sqrt{ })$ confirming the presence of $\mathrm{PCH}$. Methodology: patient's fresh serum $(2 \mathrm{~mL}$ minimum, with a $0.5 \mathrm{~mL}$ EDTA sample for grouping) was collected and maintained at $37^{\circ} \mathrm{C}$ (immerse blood sample tube immediately in thermoflask filled with $37^{\circ} \mathrm{C}$ water for transportation). Reagent P-antigen-positive group 0 $\mathrm{RBC}$ and fresh donor serum (source of complement since patients with PCH may have low complement due to prior consumption) were added. The sample was separated and subjected to heating under three conditions: (1) $4^{\circ} \mathrm{C}$ for $90 \mathrm{~min},(2) 37^{\circ} \mathrm{C}$ for $90 \mathrm{~min}$ and (3) $4^{\circ} \mathrm{C}$ for $30 \mathrm{~min}$ followed by $37^{\circ} \mathrm{C}$ for $60 \mathrm{~min}$. A positive $\mathrm{D}$ - $\mathrm{L}$ test and diagnosis of $\mathrm{PCH}$ are demonstrated when haemolysis only occurs after condition 3). ${ }^{16}$ To increase sensitivity, enzymes such as $1 \%$ papain can be used to expose more of the RBC surface P-antigens to increase possibility of binding with D-L autoantibodies. ${ }^{1} \mathrm{D}-\mathrm{L}$, DonathLandsteiner; PCH, paroxysmal cold haemoglobinuria; RBC, red blood cell. 


\begin{tabular}{|c|c|}
\hline Intravascular Haemolysis & Extravascular Haemolysis \\
\hline $\begin{array}{l}\text { Immune } \\
\text { - PCH } \\
\text { - PNH } \\
\text { - Drug-induced immune haemolytic } \\
\text { anaemia } \\
\text { - Acute haemolytic transfusion reactions } \\
\text { Thrombotic microangiopathies } \\
\text { - HUS } \\
\text { - TTP } \\
\text { - DIC } \\
\text { Mechanical Trauma } \\
\text { - Arteriovenous malformations } \\
\text { - Burns } \\
\text { Infections } \\
\text { - Malaria (blackwater fever) } \\
\text { - Clostridium perfringens }\end{array}$ & $\begin{array}{l}\text { Intrinsic RBC defects } \\
\text { - Haemoglobinopathies (e.g. sickle cell, } \\
\text { thalassemia) } \\
\text { - Enzyme deficiencies (e.g. G6PD deficiencies) } \\
\text { - Membrane defects (e.g. hereditary } \\
\text { spherocytosis) } \\
\text { Immune } \\
\text { - Warm AlHA } \\
\text { - CHAD } \\
\text { - Drug-induced immune haemolytic anaemia } \\
\text { - Delayed haemolytic transfusion reactions }\end{array}$ \\
\hline
\end{tabular}

Figure 4 Some examples of the causes of intravascular and extravascular haemolyses to be considered in a child presenting with a haemolytic picture. ${ }^{5}$ AlHA, autoimmune haemolytic anaemia; CHAD, cold agglutinin disease; DIC, disseminated intravascular coagulation; G6PD, glucose 6 phosphate dehydrogenase; HUS, haemolytic uraemic syndrome; $\mathrm{PCH}$, paroxysmal cold haemoglobinuria; PNH, paroxysmal nocturnal haemoglobinuria, RBC, red blood cell; TTP, thrombotic thrombocytopenic purpura.

to myelosuppression secondary to a recent infection or inadequate compensatory reticulocytosis. ${ }^{410}$ The patient's blood results are shown in figure 1.

Can peripheral blood films help distinguish between the type of haemolysis (ie, intravascular or extravascular) and are there any characteristics associated with AlHA?

Non-specific characteristics of blood films associated with AIHA include red cell agglutination and anisopoikilocytosis (varying size and shape of RBCs) such as schistocytes, spherocytes and polychromasia, although these can also be associated with other causes of haemolytic anaemia, for example, mycoplasma infections and lymphoproliferative disorders. ${ }^{22}$ Spherocytes tend to be a characteristic of extravascular haemolysis while intravascular haemolysis is associated with schistocytes. $^{23}$ The blood film from the 2-year-old boy, showing spherocytes and red cell agglutination, did not show any specific changes suggestive of an intravascular haemolysis (figure 2).

\begin{tabular}{|c|c|c|}
\hline Warm AlHA & Cold AlHA & Mixed AIHA \\
\hline $\begin{array}{ll}\text { Primary } \\
\text { Secondary } \\
\text { - } \quad \text { Lymphoproliferative } \\
\text { - } \text { disorders (CLL, Lymphoma) } \\
\text { - } \quad \text { Solid Tumours } \\
\text { - } \quad \text { Confection (HCV, HIV, CMV) } \\
\text { (SLE, Sjogrens syndrome) } \\
\text { - } \quad \text { Autoimmune disorders (UC, } \\
\text { - Sarcoidosis) } \\
\text { - } \text { Post transplantation }\end{array}$ & $\begin{array}{l}\text { Cold Haemagglutinin Disease } \\
\text { Primary } \\
\text { Secondary } \\
\text { - } \quad \text { Lymphoproliferative disorders (CLL, } \\
\text { NHL) } \\
\text { - } \quad \text { Solid Tumours } \\
\text { - } \quad \text { Infection (Mycoplasma pneumonia, } \\
\text { viral infections e.g. EBV, CMV) } \\
\text { - } \quad \text { Autoimmune disease } \\
\text { Paroxysmal Cold Haemoglobinuria } \\
\text { Primary } \\
\text { Secondary } \\
\text { - Viral Infections (e.g. Adenovirus, } \\
\quad \text { Influenza A, CMV, IM, VZV, Measles, } \\
\text { Mumps, E. coli) } \\
\text { - Bacterial Infections (e.g. Haemophilus } \\
\quad \text { influenzae, Mycoplasma } \\
\text { pneumoniae) } \\
\text { - } \quad \text { Post-vaccination (MMR) } \\
\text { - Syphilis - congenital or tertiary } \\
\text { - } \quad \text { Aumphoproliferative disorders } \\
\end{array}$ & $\begin{array}{l}\text { Primary } \\
\text { Secondary } \\
\text { - Lymphoma } \\
\text { - SLE } \\
\text { - Infection }\end{array}$ \\
\hline
\end{tabular}

Figure 5 Classification of AlHAs and associated aetiologies. ${ }^{26} \mathrm{AlHA}$, autoimmune haemolytic anaemia; CLL, chronic lymphocytic leukaemia; CMV, cytomegalovirus; EBV, Ebstein-Barr virus; HCV, hepatitis C virus; IM, infectious mononucleosis; MMR, measles, mumps and rubella; NHL, nonHodgkin's lymphoma; SLE, systemic lupus erythematosus; UC, ulcerative colitis; VZV, varicella zoster virus. 


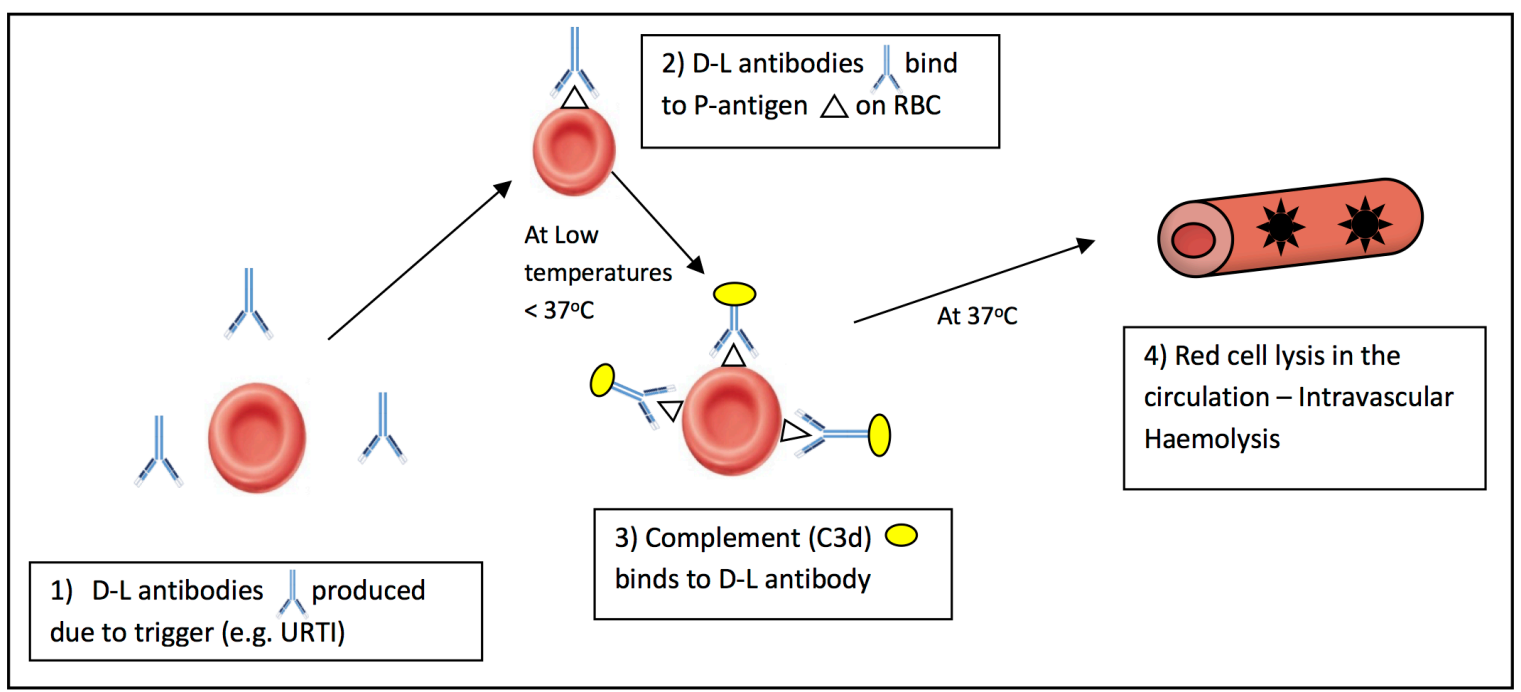

Figure 6 Suggested haemolysis in paroxysmal cold haemoglobinuria. D-L, Donath-Landsteiner; RBC, red blood cell; URTI, upper respiratory tract infection.

\section{How might you differentiate between non-immune and immune causes of haemolysis and when might you consider a D-L test for suspected PCH?}

The cause of haemolysis may be obvious and the clinician can proceed directly to specific diagnostic testing, for example, haemolysis with blood film characteristics of sickle cell or thalassemia. ${ }^{20}$ Other blood tests platelets, lymphocytes and granulocytes, renal function and coagulation screens can provide diagnostic insight and significant derangements with haemolysis may suggest more serious underlying causes, for example, TMA or clonal haematopoietic disorders.

If the cause of haemolysis is less clear, a direct antiglobulin test (DAT) can determine whether the haemolysis is immune or non-immune. ${ }^{2024}$ In the DAT screen, human antibodies against C3 and IgG are incubated with the patients' RBCs. If the surface of the RBCs is coated with IgG or C3, agglutination occurs and a DAT-positive test suggests an immune aetiology. ${ }^{24}$ DAT-positive tests can occur in other non-haemolytic diseases e.g. SLE, malignancy or renal disorders. ${ }^{1}$ Figure 8 reveals the common DAT findings in AIHA. ${ }^{1}$ A DAT-negative test does not exclude AIHA; in one series of 100 children with AIHA, DAT was negative in $21 \% .^{25}$

In $\mathrm{PCH}$, the $\mathrm{D}-\mathrm{L}$ bound $\mathrm{RBC}$ are mostly coated with C3 causing the DAT-positive for complement (C3) (DAT-positive C3) screen. Children presenting with features suggestive of intravascular haemolysis and have a DAT-positive C3 should undergo an indirect D-L test for $\mathrm{PCH} .{ }^{1}$ A DAT-negative test does not exclude $\mathrm{PCH}$; one study estimated that 1 in six children with PCH were DAT-negative. ${ }^{19}$ Consequently, a D-L test should equally be considered in children with haemolysis, haemoglobinuria and DAT-negative. ${ }^{1}$

What is the indirect $D-L$ test and are there any problems with the test in a child undergoing the D-L test?

The indirect D-L test subjects the patient's serum to appropriate cells, P-antigen-positive group $\mathrm{O} \mathrm{RBC}$ and fresh donor serum (a source of complement) and incubates at $4^{\circ} \mathrm{C}$ followed by $37^{\circ} \mathrm{C}$. Presence of the D-L antibody is confirmed by the initiation of haemolysis postsuccessive incubations. If no haemolysis occurs, theoretically the D-L antibody is absent (or a false-negative result).

\begin{tabular}{|l|c|c|}
\hline \multicolumn{1}{|c|}{ Laboratory Results } & Intravascular Haemolysis & Extravascular Haemolysis \\
\hline Reticulocyte & $\uparrow$ & $\uparrow$ \\
\hline Bilirubin (unconjugated) & $\uparrow$ & $\uparrow$ \\
\hline LDH & $\uparrow \uparrow$ & $\uparrow$ \\
\hline Haptoglobin & $\downarrow \downarrow$ & Normal/ $\downarrow$ \\
\hline Haemoglobinuria & Positive & Negative \\
\hline
\end{tabular}

Figure 7 Comparison between the typical laboratory findings in an extravascular versus an intravascular haemolysis. ${ }^{22}$ Note: Haptoglobin is not produced efficiently in children under 2 years or those with liver disease (levels are artificially low) and rises with acute inflammation, so it may be misleadingly normal in infection/inflammation despite haemolysis. LDH is non-specifically elevated in tissue damage and may remain low in extravascular haemolysis as red cells are mopped up by the reticuloendothelial system. Reticulocytes may be depressed initially because infection is often myelosuppressive and then rebound. $\uparrow \uparrow$, significantly increased; $\uparrow$, increased; $\downarrow$, decreased; $\downarrow \downarrow$, significantly decreased; LDH, lactate dehydrogenase. 
Figure 3 shows the positive D-L test of the patient and gives further information on the D-L test. The test takes approximately 24 hours in a weekday and 72 hours on a weekend and may need performing at a specialist immunohaematology centre, incurring delays if transport is limited. The lab will appreciate forewarning, and the test costs approximately $£ 108$.

The most common cause of false-negative D-L tests are low and undetectable D-L antibody titres. ${ }^{26}$ This can be due to the rate at which the D-L antibody disappears from plasma during patient recovery. ${ }^{26}$ Using fresh donor serum as the source of complement and maintaining the patient's serum sample at $37^{\circ} \mathrm{C}$ should reduce the incidence of false-negative tests. False-positive results have occurred in cases where a patient has CHAD and IgM autoantibodies. ${ }^{27}$ More accurate estimation of the sensitivity and specificity of the D-L test is limited by technical issues (transport to a regional haematology lab given the temperature requirements) and infrequent use.

\section{How does a positive D-L test and subsequent diagnosis of PCH influence management of a child who presented with an acute haemolysis?}

Management of $\mathrm{PCH}$ has primarily been supportive: cold avoidance, maintaining a warm ambient temperature (prewarming all intravenous fluids and transfusions), giving transfusions as required and folic acid supplementation to avoid megaloblastosis. ${ }^{141516}$ Simultaneous treatment of relevant underlying causes should be undertaken, for example, persistent bacterial infections or syphilis. Corticosteroids have previously been used, although there is significant uncertainty regarding efficacy due to the transient nature of haemolysis. ${ }^{4102728}$ Children tend to be treated with corticosteroids initially (prednisolone $1 \mathrm{mg} /$ $\mathrm{kg}$ daily like in warm AIHA), as a precautionary step. ${ }^{29}$ Once PCH has been diagnosed, corticosteroids can be stopped with the exception of severe or refractory disease where a 1-week trial of corticosteroids would be considered. ${ }^{125}$ Other medications considered in AIHA can also be avoided with a $\mathrm{PCH}$ diagnosis including immunosuppressants (rituximab). ${ }^{1}$ For refractory, chronic or recurrent $\mathrm{PCH}$ case reports for immunosuppressive therapies (rituximab, intravenous IgG or eculizumab (humanised anti-C5 monoclonal antibody)) exist, but robust trials are needed. ${ }^{430}$

$\mathrm{PCH}$ is usually self-limiting and tends to resolve spontaneously when the viral illness or trigger has subsided. ${ }^{14} 15$ As an intravascular haemolysis, it can rapidly become life-threatening with a severe progressive anaemia and acute kidney injury secondary to haem pigment nephropathy. ${ }^{31}$ Renal function must be monitored frequently; adequate renal perfusion must be maintained; and nephrotoxic drugs, for example, NSAID-based antipyretics, must be avoided. ${ }^{31}$

Transfusions to maintain $\mathrm{Hb}$ at a clinically acceptable level are indicated when a child develops hypoxaemia, cardiac decompensation or a rapidly progressive anaemia. ${ }^{6}$ Children tend to compensate better for a falling $\mathrm{Hb}$ and transfusions are usually given when $\mathrm{Hb}$ is $<5-6 \mathrm{~g} / \mathrm{L}$ (above this consider child's clinical status). ${ }^{29}$ The laboratory must be informed of the diagnosis so that pretransfusion testing can be performed above the thermal amplitude of the D-L antibody to avoid agglutination and delays to transfusions.

To monitor disease progression and recovery regular blood tests for $\mathrm{Hb}$, reticulocytes, bilirubin and $\mathrm{LDH}$ should be done. ${ }^{29}$ An increase in reticulocytes, usually within 3-5 days, is an important marker of recovery in haemolysis. ${ }^{5}$ Likewise, a decrease in $\mathrm{LDH}$ corresponds with a reduction in the haemolytic rate..$^{5}$ After initial recovery, monthly blood tests would be reasonable and can be discontinued after two consecutive normal results. $^{29}$

With the reduced incidence of congenital syphilis, $\mathrm{PCH}$ is no longer viewed as a chronic disorder, and characteristically, once resolved it rarely reoccurs with long-term prognosis being favourable. ${ }^{13} 16$ The family must be counselled on how to recognise future episodes of AIHA as, although rare, reports have highlighted $\mathrm{PCH}$ recurrence up to 21 months after initial presentation. ${ }^{32}$ Where $\mathrm{PCH}$ persists or resolution is slow, a paediatric haematology opinion may help in looking for rarer causes, for example, lymphoproliferative disorders. ${ }^{29}$

Management: The patient was initially treated with folic acid, steroids, blood transfusions and intravenous ceftriaxone to cover for any bacterial infections. Due to vascular compromise, he required a femoral line. We maintained a warm environment, minimised exposure to cold and gave fluids and blood through a warmer. A positive D-L test confirmed PCH and the steroids were stopped. After 10 days, he was discharged home once haemodynamically stable and his $\mathrm{Hb}$ showed a consistent upward trend. We continued to monitor his recovery for 4 weeks as an outpatient until his reticulocytosis had resolved (reticulocytes $=62 \times 10^{9} / \mathrm{L}$ ); $\mathrm{Hb}$ returned to the normal level $(\mathrm{Hb}=128 \mathrm{~g} / \mathrm{L})$; and there was no further evidence of haemolysis. The patient did develop a thrombus in his femoral line and this was successfully treated with Dalteparin alongside his PCH. Advice was given to the family on recognising the clinical signs of acute haemolysis and when to seek medical attention should any further episodes occur.

\section{CONCLUSION}

$\mathrm{PCH}$ is a rare but one of the most common causes of AIHA in children. We demonstrate how the use of the D-L test diagnosed our 2-year-old boy with $\mathrm{PCH}$ and helped with subsequent management and avoiding unnecessary treatments, for example, steroids and immunosuppressants. It is reasonable to perform the $\mathrm{D}-\mathrm{L}$ test in children with evidence of intravascular haemolysis and/or a DAT-positive C3 test. From a paediatrician's perspective, ensuring the laboratory 


\begin{tabular}{|l|c|c|c|c|}
\hline & Warm AlHA & Mixed AlHA & CHAD & PCH \\
\hline $\begin{array}{l}\text { Typical DAT } \\
\text { Finding }\end{array}$ & IgG or IgG + C3 & IgG + C3 & C3 & C3 \\
\hline
\end{tabular}

Figure 8 Common DAT findings associated with different AlHAs. ${ }^{13}$ AlHA, autoimmune haemolytic anaemia; CHAD, cold haemagglutinin disease; PCH, paroxysmal cold haemoglobinuria.

is forewarned and keeping the sample at $37^{\circ} \mathrm{C}$ help maximise the quantity of antibody in the serum and the likelihood of performing a D-L test correctly.

\section{Test your knowledge}

1. What are the typical laboratory findings in patients with intravascular haemolysis?

A. Raised bilirubin, raised haptoglobin, low haemoglobin $(\mathrm{Hb})$, raised lactate dehydrogenase (LDH).

B. Raised bilirubin, low haptoglobin, low $\mathrm{Hb}$, raised LDH, haemoglobinuria.

C. Low bilirubin, low haptoglobin, low $\mathrm{Hb}$, raised LDH, haemoglobinuria.

D. Low bilirubin, raised haptoglobin, low $\mathrm{Hb}$, raised LDH.

2. Direct antiglobulin test (DAT) testing in paroxysmal cold haemoglobinuria $(\mathrm{PCH})$ is likely to reveal the following:

A. DAT testing: IgG positive, $C 3$ negative.

B. DAT testing: IgG negative, $C 3$ negative.

C. DAT testing: IgG negative or positive, C3 positive.

3. Donath-Landsteiner (D-L) antibody is classically a biphasic haemolysin. What does this mean with regards to $\mathrm{PCH}$ ?

A. D-L antibody fixes complement to red blood cells (RBCs) at low temperatures $\left(<37^{\circ} \mathrm{C}\right)$ and haemolysis is triggered when the blood is rewarmed to $37^{\circ} \mathrm{C}$.

B. D-L antibody fixes complement to RBCs at $37^{\circ} \mathrm{C}$ and triggers haemolysis.

C. D-L antibody fixes complement to RBCs at low temperatures $\left(<37^{\circ} \mathrm{C}\right)$ and triggers haemolysis.

D. D-L antibody fixes complement to RBCs at $37^{\circ} \mathrm{C}$ and haemolysis is triggered when the blood is cooled to $4^{\circ} \mathrm{C}$.

4. There is little evidence to suggest that steroids are effective in the management of $\mathrm{PCH}$. True or false?

5. Performing the $D-L$ test is difficult. What must clinicians remember to do if they want the test to be successful?

A. Maintain temperature of the serum sample at $37^{\circ} \mathrm{C}$ until the test is carried out.

B. Take the blood test in the evening.

C. Maintain temperature of the serum sample at $4^{\circ} \mathrm{C}$ until the test has been carried out.

D. Doesn't matter what temperature the serum sample is kept at on transfer to the lab.

Answers to the quiz are at the end of the references

\section{TOPICS FOR FURTHER RESEARCH}

1. The role of the D-L test in DAT-negative AIHAs.

2. Sensitivity and specificity of the D-L test.

Acknowledgements We are grateful for the information and assistance of the Poole Pathology and Severn Pathology services in the preparation of this article.

Contributors JDW, HK and MPT conceived the article. JDW wrote the article, with assistance from HK and MPT, and edited the article for publication. RKJ gave haematological advice. All authors are accountable for this work.

Funding The authors have not declared a specific grant for this research from any funding agency in the public, commercial or not-for-profit sectors.

Competing interests None declared.

Patient consent for publication Parental/guardian consent obtained.

Provenance and peer review Commissioned; externally peer reviewed.

Supplemental material This content has been supplied by the author(s). It has not been vetted by BMJ Publishing Group Limited (BMJ) and may not have been peer-reviewed. Any opinions or recommendations discussed are solely those of the author(s) and are not endorsed by BMJ. BMJ disclaims all liability and responsibility arising from any reliance placed on the content. Where the content includes any translated material, BMJ does not warrant the accuracy and reliability of the translations (including but not limited to local regulations, clinical guidelines, terminology, drug names and drug dosages), and is not responsible for any error and/or omissions arising from translation and adaptation or otherwise.

Open access This is an open access article distributed in accordance with the Creative Commons Attribution Non Commercial (CC BY-NC 4.0) license, which permits others to distribute, remix, adapt, build upon this work noncommercially, and license their derivative works on different terms, provided the original work is properly cited, appropriate credit is given, any changes made indicated, and the use is non-commercial. See: http://creativecommons.org/ licenses/by-nc/4.0/.

\section{ORCID iDs}

Jennifer Delun Williams http://orcid.org/0000-0001-5130-5849

Mark Peter Tighe http://orcid.org/0000-0003-0755-8296

\section{REFERENCES}

1 Hill QA, Stamps R, Massey E, et al. The diagnosis and management of primary autoimmune haemolytic anaemia. $\mathrm{Br} \mathrm{J}$ Haematol 2017;176:395-411.

2 Oneal PA, Schechter GP, Rodgers GP. Haemolytic Anaemia. In: The Bethesda Handbook of clinical haematology. $3^{\text {rd }}$ edn, 2013: 22-4.

3 Gehrs BC, Friedberg RC. Autoimmune hemolytic anemia. Am J Hematol 2002;69:258-71.

4 Lau-Braunhut SA, Stone H, Collins G, et al. Paroxysmal cold hemoglobinuria successfully treated with complement inhibition. Blood Adv 2019;3:3575-8.

5 Barcellini W, Fattizzo B. Clinical applications of hemolytic markers in the differential diagnosis and management of hemolytic anemia. Dis Markers 2015;2015:1-7.

6 Barros M, Langhi Jr D, Bordin JO. Autoimmune hemolytic anaemia: transfusion challenges and solutions. Int J Clin Transfus Med 2017;5:9-18.

7 Michel M. Classification and therapeutic approaches in autoimmune hemolytic anemia: an update. Expert Rev Hematol 2011;4:607-18. 
8 Aladjidi N, Jutand M-A, Beaubois C, et al. Reliable assessment of the incidence of childhood autoimmune hemolytic anemia. Pediatr Blood Cancer 2017;64:e26683.

9 Sokol RJ, Hewitt S, Stamps BK. Autoimmune haemolysis: an 18-year study of 865 cases referred to a regional transfusion centre. Br Med J 1981;282:2023-7.

10 Heddle NM. Acute paroxysmal cold hemoglobinuria. Transfus Med Rev 1989;3:219-29.

11 Habibi B, Homberg JC, Schaison G, et al. Autoimmune hemolytic anemia in children. A review of 80 cases. Am J Med 1974;56:61-9.

12 Mackenzie GM. Paroxysmal hemoglobinuria: a review. Medicine 1929;8:159-92.

13 Shanbhag S, Spivak J. Paroxysmal cold hemoglobinuria. Hematol Oncol Clin North Am 2015;29:473-8.

14 Bass GF, Tuscano ET, Tuscano JM. Diagnosis and classification of autoimmune hemolytic anemia. Autoimmun Rev 2014;13:560-4.

15 Salido EJ, Cabañas V, Berenguer M, et al. Serological findings in a child with paroxysmal cold haemoglobinuria. Case Rep Med 2014;2014:1-3.

16 Sanford KW, Roseff SD. Detection and significance of DonathLandsteiner antibodies in a 5-year-old female presenting with hemolytic anemia. Lab Med 2010;41:209-12.

17 Whipple NS, Moreau DAB, Moulds JM, et al. Paroxysmal cold hemoglobinuria due to an IgA Donath-Landsteiner antibody. Pediatr Blood Cancer 2015;62:2044-6.

18 Karafin MS, Shirey RS, Ness PM, et al. A case study of a child with chronic hemolytic anemia due to a Donath-Landsteiner positive, IgM anti-I autoantibody. Pediatr Blood Cancer 2012;59:953-5.

19 Vaglio S, Arista MC, Perrone MP, et al. Autoimmune hemolytic anemia in childhood: serologic features in 100 cases. Transfusion 2007;47:50-4.

20 Brodsky RA. Diagnosis of hemolytic anaemia in adults. Waltham, MA: UpToDate, 2021.

21 Teachey DT, Seif AE, Grupp SA. Advances in the management and understanding of autoimmune lymphoproliferative syndrome (Alps). Br J Haematol 2010;148:205-16.
22 Hill A, Hill QA. Autoimmune hemolytic anaemia. Haematology Am Soc Hematol Educ Program 2018;1:382-9.

23 Sey MSL, Manlucu J, Myers KA. Intravascular hemolysis secondary to aorto-atrial fistula presenting as red urine. J Gen Intern Med 2010;25:1370-4.

24 Zantek ND, Koepsell SA, Tharp DR, et al. The direct antiglobulin test: a critical step in the evaluation of hemolysis. Am J Hematol 2012;87:707-9.

25 Bain BJ, Win N. Acquired haemolytic anaemias. In: Dacie and Lewis practical haematology. Elsevier, 2006: 239-70.

26 Eder AF. Review: acute Donath-Landsteiner hemolytic anemia. Immunohematology 2005;21:56-62.

27 Wolach B, Heddle N, Barr RD. Transient Donath-Lansteiner haemolytic anaemia. Br J Haematol 1984;72:245-434.

28 Vagace JM, Bajo R, Gervasini G. Diagnostic and therapeutic challenges of primary autoimmune haemolytic anaemia in children. Arch Dis Child 2014;99:668-73.

29 Brugnara C, Barcellini W. Paroxysmal cold hemoglobinuria. Waltham, MA: UpToDate, 2020.

30 Koppel A, Lim S, Osby M, et al. Rituximab as successful therapy in a patient with refractory paroxysmal cold hemoglobinuria. Transfusion 2007;47:1902-4.

31 McNaughten B, Mallett T, O'Connor M. Acute kidney injury in a child with paroxysmal cold haemoglobinuria. J Clin Med Case Reports 2016;3:3.

32 Prince SD, Winestone LE, Nance SJ, et al. Recurrent DonathLandsteiner hemolytic anemia: a pediatric case report. Transfusion 2017;57:1401-6.

\section{Answers to the multiple choice questions}

1. $B$

2. $C$

3. A

4. True

5. A 